\title{
Not novel, just better: competition between native and non-native plants in California grasslands that share species traits
}

\author{
Jeffrey D. Corbin · Carla M. D'Antonio
}

Received: 18 May 2009/Accepted: 13 January 2010/Published online: 2 February 2010

(C) The Author(s) 2010. This article is published with open access at Springerlink.com

\begin{abstract}
Invasive plants have often been shown to possess novel traits such as the ability to fix nitrogen, access unused resource pools, or the ability to exude allelopathic chemicals. We describe a case of a successful invasion where the native and non-native species are very similar in most life-history characteristics including their growth forms, lifespan, and degree of summertime activity. Data from permanent transects suggest that exotic perennial grass invaders can establish into intact native-dominated grasslands, achieving cover values from 6 to $71 \%$ over several years. We also established a 4-year competition experiment to test the effect of each group-the native and non-native perennial grasses-on the other. Competitive interactions were found to consistently favor the non-native grasses: native perennial grass productivity was significantly lower in plots with exotic perennial grasses as compared to plots without exotic perennial grasses. By contrast, productivity of the exotic perennial grasses was not reduced by the presence of the native perennial grasses. These results suggest that competitive
\end{abstract}

J. D. Corbin $(\varangle)$

Department of Biological Sciences, Union College,

Schenectady, NY 12308, USA

e-mail: corbinj@union.edu

C. M. D’Antonio

Donald Bren School of Environmental Science and Management, University of California, Santa Barbara, CA 93106-3101, USA ability, rather than a unique trait, has contributed to the success of the exotic perennial grasses in our system. Management tools to control exotic perennial grass invasions are likely to negatively influence native perennial grass populations, as strategies that succeed against the invasive species may kill or reduce the native species as well.

Keywords Invasive species - Novel weapons · Holcus lanatus . Exotic perennial grasses . Native perennial bunchgrasses

\section{Introduction}

Many models of species invasions assume that successful invasions are more likely where the nonnative species possesses unique life-history or physiological traits that are not present in the native community (e.g., Elton 1958; Funk et al. 2008). Unique traits such as the ability to fix nitrogen (e.g., Vitousek et al. 1987; Stock et al. 1995), tolerate or promote the spread of fire (D'Antonio and Vitousek 1992; Knapp 1996) or alter plant-soil feedbacks (Callaway et al. 2004) may confer significant competitive advantages and contribute to the likelihood of successful invasion and impact. On the other hand, certain life-history strategies may be more successful than others in a given habitat; so successful invaders are likely to share characteristics with the native 
community. For example, the "habitat matching hypothesis" of Stohlgren et al. (2005) predicts that habitats are most likely to be invaded by species that share traits with resident species.

The implications for restoration of habitats invaded by non-native species are different depending on the similarities between the native and nonnative populations. If the native and non-native species are very different from one another in lifeform, life-history characteristics, phenology, or physiological traits, then management of non-native species - such as prescribed fire, grazing, or biological control-may be designed so as to minimize effects on other species in the community. On the other hand, if the native and non-native species are generally similar and share a variety of characteristics, then many management strategies are likely to influence both target and non-target species in similar ways. This presents a greater challenge to efforts to control invasive species (Simberloff and Stilling 1996; Kotanen 1997).

Coastal California grasslands offer a contrast of life-history characteristics among invading species that allows a comparison of the impacts of non-native species that share many traits with the native community versus non-native species that have distinct traits. The native flora of coastal prairies is made up of perennial bunchgrasses and forbs that can live for decades and develop extensive root systems to survive the summer drought that is characteristic of California's Mediterranean climate (Heady 1988; Ford and Hayes 2007). Annual grasses and forbs native to Europe and Asia invaded these and other California grassland habitats beginning in the nineteenth century. The annual species differ from the native perennial bunchgrasses in that they complete their entire life cycle before the start of the summer drought, and produce abundant seeds that germinate readily with the beginning of the growing season each fall (Heady 1958; Chiariello 1989; Corbin et al. 2007). The distinct seasonality and life span of the non-native annuals, while likely playing a role in their success, have also provided management opportunities that focus on negatively affecting the nonnative grasses without affecting native populations (Corbin et al. 2004). Such strategies include carefully timed grazing (Huntsinger et al. 2007; Marty 2005), prescribed fire (Reiner 2007), and mowing (Maron and Jefferies 2001; Stromberg and Kephart 1996).
In recent decades, another group of speciesperennial grasses from Europe and Asia-has invaded coastal California grasslands and displaced both native perennial and exotic annual populations. These exotic perennial grasses share most of their life-history characteristics with the native perennial grasses including their growth form, lifespan, reliance on summer fog (Corbin et al. 2005), degree of summertime activity and allocation of resources to roots versus shoots (Thomsen et al. 2006; Corbin and D'Antonio, unpublished manuscript). It is not known the extent to which these new invaders may influence growth and survival of intact native perennial grasses. Several surveys of coastal prairie grasslands have reported relatively high abundances of exotic perennial grasses even in those communities where exotic annual grasses are nearly absent (e.g., Foin and Hektner 1986; Heady 1988; Peart 1989; Stromberg et al. 2001), and anecdotal reports suggest that their range and abundance are increasing.

The purposes of this study are to: (1) examine trends in exotic perennial grass abundance in a native-dominated grassland and to test whether abundance is increasing over time; (2) examine competitive interactions among native and exotic perennial grasses in experimental field plots in order to test whether the non-natives affect the growth or survival of the natives; (3) qualitatively compare the impacts of exotic perennial grasses on the productivity and survival of native perennial grasses to the impacts of exotic annual grasses that we have measured at this same site (Corbin and D'Antonio 2004b). We consider each of these comparisons in the context of efforts to design management strategies to control the exotic perennial grasses and increase the abundance of native species in coastal prairie grasslands.

\section{Methods}

Study site

Our study was conducted at Tom's Point Preserve, a private nature preserve adjacent to Tomales Bay in Marin County, CA $\left(38^{\circ} 13^{\prime} \mathrm{N}, 122^{\circ} 57^{\prime} \mathrm{W}\right)$, administered by Audubon Canyon Ranch. The site has not been grazed since at least 1975; the area where our experimental treatments were established is an 
uplifted marine terrace approximately $30 \mathrm{~m}$ above sea level which may have been tilled for farming in the early part of the twentieth century. Northern coastal California experiences highly seasonal rainfall patterns typical of Mediterranean climates. Mean annual precipitation is $790 \mathrm{~mm}$ per year, mainly falling between November and April. During the course of this study, annual rainfall varied over twofold: 1197, 711, 476, and $858 \mathrm{~mm}$ from 19981999 to 2001-2002, respectively (Corbin and D'Antonio 2004b). Mean monthly temperature ranges from $13.9^{\circ} \mathrm{C}$ in March to $18.1^{\circ} \mathrm{C}$ in September.

\section{Grassland survey}

Four 50-m transects were established at Tom's Point in May 1999 in portions of the preserve in which native perennial grass cover exceeded $60 \%$. There is no evidence that cultivation ever took place in these areas (J. Kelly, personal communication). The transects were laid out parallel to the shoreline, and all were at least $10 \mathrm{~m}$ from any other. Vegetation composition along each transect was sampled using a point-intercept method. A 2-mm pole was dropped vertically to the soil surface every $50 \mathrm{~cm}$, and all plant species touching the pole were recorded. Percent cover for each species was calculated based on the proportion of 100 possible "contact points" in which a species was recorded. We also recorded whether the pole was touching bare soil or plant litter. Each species' percent cover was summed to produce a cumulative proportional cover that could exceed $100 \%$. Sampling was performed in 1999, 2001, 2002, 2003, 2005, 2006, and 2008, though a taxonomic discrepancy caused us to leave out native species cover designations in 1999.

\section{Competition experiment}

Seeds of the native perennial grasses Agrostis oregonensis Vasey, Festuca rubra L., and Nassella pulchra A. Hitchcock (Barkworth) and the introduced perennial grasses Festuca arundinacea Schreber, Holcus lanatus L., and Phalaris aquatica L. were collected on-site in Spring 1998. Seeds were planted in individual Conetainers (Stewe and Sons, Corvallis, OR, USA) in September 1998 and allowed to germinate under greenhouse conditions.
In September 1998, we established experimental plots in a portion of Tom's Point Preserve dominated by non-native species including perennial grasses, annual grasses, and annual and biennial forbs. Detailed description of the experimental design can be found in Corbin and D'Antonio (2004a, b). We hand cleared standing vegetation after applying a solution of $5 \%$ glyphosate herbicide. We created a series of $1.5 \mathrm{~m} \times 1.5 \mathrm{~m}$ plots, each of which was randomly assigned to one of five treatments: native perennial bunchgrasses only (NP), exotic perennial grasses only (EP), exotic annual grasses only (EA), native and exotic perennials $(\mathrm{NP}+\mathrm{EP})$, and native perennials grown with exotic annuals (NP + EA). Density was held constant for $\mathrm{NP}, \mathrm{EP}$, and NP + EP treatments. Corbin and D'Antonio (2004b) described the results from treatments with exotic annual grasses (EA) and natives and exotic annual grasses together $(\mathrm{NP}+\mathrm{EA})$; so we present these treatments for comparison only in the discussion.

We transplanted the greenhouse-grown seedlings into appropriate plots between January 5 and 14 , 1999 using a 2.5-mm soil corer to dig holes. Each plot received 144 seedlings, arranged in a 12 plant $\times 12$ plant grid. Each plant was separated from its neighbor by $12 \mathrm{~cm}$. The NP and EP plots each received 144 native perennial and exotic perennial plants, respectively; the NP + EP plots received 72 plants of each type evenly divided among the three species in each category. Within a plot, the seedlings were organized into "species neighborhoods" made up of four plants of the same species (36 groups per plot). Location of the neighborhoods in each plot was random, though the placement was constrained so that each species had at least one neighborhood in the central $1 \mathrm{~m}^{2}$ of each grid. Dead individuals were replaced for the 1st month, but seedling survival after transplanting was very high ( $>99 \%$ for all species for the first 2 years). Plots were weeded of dicots and nontarget grasses three times each year to maintain species composition and density, although after the first 2 years very little weeding was required.

Aboveground biomass of the grasses was sampled twice each season using nondestructive methods (see Corbin and D'Antonio 2004a, b). We constructed allometric relationships between basal diameter, longest leaf length, and the number of flowering culms and the aboveground biomass for each species. 
The $r^{2}$ of the allometric equations for each species was greater than 0.85 , with the exception of $H$. lanatus, which had an $r^{2}$ of 0.68 . In the first season, plants were measured 1 month after transplanting (March 1999) and again in July 1999, at the end of the growing season. In years 2-4, plants were measured once in the fall (October 1999 or November 2000, 2001), and again in early summer (June 2000, 2001, 2002) to coincide with the minimum and maximum plant sizes, respectively. Productivity each season was calculated as the difference between each plant's maximum biomass in the early summer and its minimum biomass in the fall, or in March 1999 in the case of year 1 .

Reproductive output of each species was estimated in June 2001 by harvesting inflorescences of three randomly selected individuals in each plot. Seeds of all species except $N$. pulchra were dried $\left(60^{\circ} \mathrm{C}\right)$ to constant mass and weighed. Because of its earlier flowering time, many $N$. pulchra seeds had already matured and dropped. N. pulchra inflorescences have one floret per spikelet and the glumes are persistent on the flowering culms; so the number of seeds per plant was determined by counting the number of spikelets.

\section{Statistical analysis}

The transect data were not analyzed statistically because we lack replication at any one site.

We used repeated measures ANOVA (SAS Institute 2002) to test species' productivity (e.g., exotic perennials with and without native perennials, and native perennials with and without exotic perennials). The model used included competition, year, and the interaction between year and competition. The effects of year and the year $x$ competition interactions were analyzed with MANOVA using Roy's Greatest Root (Scheiner 1993). Though year $\times$ competition interactions were not significant $(P>0.1)$, we ran separate ANOVAs for each year's vegetative productivity and linear contrasts between year and competition to test whether there was a trend in the response of native or exotic vegetation over the course of the experiment. The effect of competition on each species' reproductive output was also analyzed using ANOVA. All variables were log-transformed to meet the assumptions of ANOVA.

\section{Results}

Vegetation surveys

Native perennial grasses dominated or co-dominated the cover on all four of the vegetation transects throughout the 8 years of observation (Fig. 1). Transects 1 and 2 were strongly dominated by the native grasses Festuca rubra and Deschampsia caespitosa, with cumulative native perennial grass cover above $120 \%$ in all 4 years. Transects 3 and 4 were on a west-facing slope with drier soils (D'Antonio, unpublished data) and higher cover of exotic annual and perennial grasses. Even on those two transects, native perennial grasses still had the highest cumulative cover of the three groups in every year but one, ranging between 68 and 113 (Fig. 1). There was a slight increase in cover of the native perennial grasses on all four transects from 2001 through 2008.

Exotic annual and perennial grasses were found on all four transects, though with the exception of Transect 4 their cover was lower than the cover of native perennial grasses (Fig. 1). Mean cumulative cover of exotic perennial grasses, including Festuca arundinacea, Holcus lanatus, and Phalaris aquatica, and Lolium perenne L. ranged from 6\% in Transect 2 in 1999 to a peak of 71 in Transect 3 in 2001. The higher cover for exotic perennial grasses on Transects 3 and 4 compared to Transects 1 and 2 was largely due to higher cover of $L$. perenne, which was nearly absent from Transects 1 and 2. Cumulative cover of exotic annual grasses was similar to that of the exotic perennial grasses, except on Transect 4 where it was as high as 100 . The most frequently observed exotic annual grasses were small grasses such as Aira caryophyllea L., Bromus hordeaceous L., Vulpia myuros (L.) C. Gmelin rather than the larger Avena barbata Link or Bromus diandrus Roth. The latter two were common only on Transect 3 .

\section{Competitive interactions}

Survival of native and exotic perennial grasses through the end of the third growing season (20002001) in experimental plots was not significantly different $(P>0.1)$ between treatments for any of the six species. Survival was $>90 \%$ for all of the species except $N$. pulchra and $H$. lanatus, which had 
Fig. 1 Cumulative cover of native perennial (filled circle), exotic perennial (filled triangle), and exotic annual (filled square) grasses in four 50-m transects between 1999 and 2008. Cover of native perennial grasses was not recorded in 1999.

Cumulative cover is greater than $100 \%$ due to multilayer canopy. Grass cover was estimated using pointintercept method (see "Methods" for details)

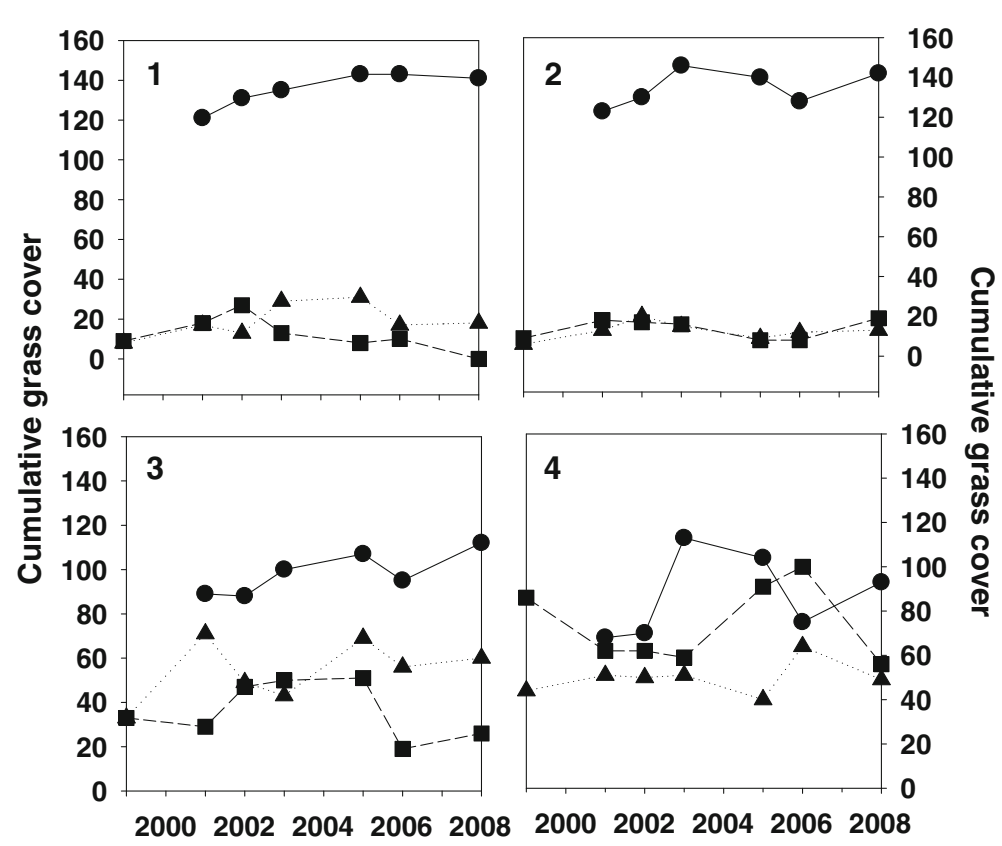

experiment-wide survival rates of 79 and $66 \%$, respectively.

Productivity of native and exotic perennial grasses varied by year, likely due to rainfall (Tables 1, 2: year). Overall, productivity of exotic perennial grasses was greater than that of native perennial grasses across all competition treatments. Furthermore, exotic perennial grasses had a significant negative effect on the mean aboveground productivity of native perennial grasses and on the productivity of two of the three individual species of native perennial grasses (Table 1; Figs. 2, 3a). The influence of competition was consistent across years (Table 1; year $\times$ competition, $P>0.3$ ). Only in 1999-2000 was there no influence of exotic perennial grasses on the productivity of native species (Fig. 2).

By contrast, the presence of native perennial species either had no significant effect or a transient positive effect on exotic perennial aboveground productivity (Table 2; Figs. 2, 3a). For example, the first-year productivity of Festuca arundinacea $(P<0.08)$ and Holcus lanatus $(P<0.02)$ was higher in NP + EP plots as compared to EP plots (Fig. 2).

Competition treatments also had a significant effect on the reproductive output of the plants in this experiment. The number of seeds produced by all three native perennial grasses was lower in the presence of exotic perennials than when only natives were present. However, only for $N$. pulchra was this statistically robust (Table 3 ). Meanwhile, the seed mass of $P$. aquatica and $F$. arundinacea tended to be higher $(P<0.10)$ in the presence of native perennials than when competing among themselves (Table 3 ).

\section{Discussion}

Our repeated survey of the grassland at Tom's Point revealed that exotic perennial grasses were able to invade relatively undisturbed native-dominated coastal prairie. Their cover increased in three of the four transects over the 9-year time period. In spite of the presence of exotic perennial grasses throughout the grassland, the cover of native species also increased in all four transects between 2001 and 2008. Regardless of the reasons for these increases, the observations suggest that both groups of species respond similarly to the environment. Other studies have also found exotic perennial grasses to be an important component of coastal prairie grasslands in California-frequently substantially more important than exotic annual species (e.g., Heady 1988; Peart 1989; Stromberg et al. 2001; Ford and Hayes 2007). Indeed, cumulative exotic annual grass cover in our surveys was below $50 \%$ on three of the four transects, and even on Transect 4, where their cumulative cover 
Table 1 Repeated measures ANOVA testing the effect of competition with exotic perennial species on log-transformed productivity of native perennial species

\begin{tabular}{|c|c|c|c|c|c|c|c|c|c|c|c|c|}
\hline & \multicolumn{3}{|c|}{ Mean native productivity } & \multicolumn{3}{|c|}{ Agrostis } & \multicolumn{3}{|c|}{ F. rubra } & \multicolumn{3}{|c|}{ Nassella } \\
\hline & $F$ & d.f. & $P<F$ & $F$ & d.f. & $P<F$ & $F$ & d.f. & $P<F$ & $F$ & d.f. & $P<F$ \\
\hline Competition with exotics & 13.1 & 1,13 & 0.004 & 1.7 & 1,13 & 0.3 & 41.4 & 1,13 & 0.0001 & 7.7 & 1,12 & 0.02 \\
\hline Year & 17.0 & 3,39 & 0.0001 & 1.1 & 3,39 & 0.4 & 40.4 & 3,39 & 0.0001 & 10.2 & 3,36 & 0.001 \\
\hline Year $\times$ competition & 1.0 & 3,39 & 0.4 & 0.5 & 3,39 & 0.7 & 1.5 & 3,39 & 0.3 & 0.4 & 3,36 & 0.7 \\
\hline
\end{tabular}

See Fig. 2 for results of single-season ANOVA. Due to mortality in some plots, d.f. varied by species. Bold indicates effects significant $<0.10$

Table 2 Repeated measures ANOVA testing the effect of competition with native perennial species on log-transformed productivity of exotic perennial species

\begin{tabular}{|c|c|c|c|c|c|c|c|c|c|c|c|c|}
\hline & \multicolumn{3}{|c|}{ Mean exotic productivity } & \multicolumn{3}{|c|}{ F. arundinaceae } & \multicolumn{3}{|c|}{ Holcus } & \multicolumn{3}{|c|}{ Phalaris } \\
\hline & $F$ & d.f. & $P<F$ & $F$ & d.f. & $P<F$ & $F$ & d.f. & $P<F$ & $F$ & d.f. & $P<F$ \\
\hline Competition & 0.1 & 1,12 & 0.8 & 0.1 & 1,10 & 0.9 & 1.2 & 1,10 & 0.4 & 1.5 & 1,12 & 0.3 \\
\hline Year & 2.8 & 3,36 & 0.09 & 63.3 & 3,30 & 0.0001 & 4.9 & 3,30 & 0.05 & 2.4 & 3,36 & 0.3 \\
\hline Year $\times$ competition & 1.6 & 3,36 & 0.2 & 1.2 & 3,30 & 0.4 & 1.7 & 3,30 & 0.3 & 0.8 & 3,36 & 0.5 \\
\hline
\end{tabular}

See Fig. 2 for results of single-season ANOVA. Due to mortality in some plots, d.f. varied by species. Bold indicates effects significant $<0.10$

reached $100 \%$, the exotic annual species were almost exclusively of short stature and occupied interstitial spaces between mature native bunchgrasses. Of the most abundant exotic annual species detected, only $V$. myuros is included in the California Invasive Plant Council's Invasive Plant Inventory (Cal-IPC 2006) and it is not considered one of the more harmful species.

Our experimental comparisons showed strong evidence that exotic perennial grasses reduce native grass growth, though there was no effect of exotic perennial grasses on native grass survival. The competitive interactions during the 4-year experiment were asymmetric: the exotic perennial grasses reduced the productivity and reproductive output of two of the native perennial grasses (Festuca rubra and Nassella pulchra), but the native grasses did not reduce the productivity or reproductive output of the exotic perennial grasses. In fact, the productivity and seed mass of some of the exotic perennial species were higher in the NP + EP treatment as compared to the EP treatment. Given that the density of exotic perennial grasses in NP + EP plots was half that of EP plots, it appears that exotic perennial grasses were inhibiting each other in the EP plots to a greater extent than in the NP + EP plots.
Our results are broadly consistent with the findings of Thomsen et al. (2006), who used a greenhouse experiment to test the pair-wise competitive interactions of the same native and exotic perennial species at the seedling stage. They found that these exotic perennial species had a greater effect on neighbors (native or exotic) than did the native species. The interactions between $H$. lanatus or $F$. arundinacea versus $F$. rubra or $N$. pulchra were found to be asymmetric, favoring the non-native species. Thomsen et al. (2006) also found that H. lanatus seedlings had the strongest negative effect on the productivity of its neighbors compared to the effects of $F$. arundinacea and $P$. aquatica. This contrasts with our observation that $H$. lanatus' productivity declined each year while the biomass of the largest of the exotic perennials, $F$. arundinacea, increased over the 4-year period (Fig. 2). It is possible that the most competitive individuals changed through the course of our field experiment $-H$. lanatus may have been the most competitive in early stages of community establishment as it was in the greenhouse experiment of Thomsen et al. (2006), but $F$. arundinacea exerted the greatest impact as the plants aged and biomass in the stand increased. Also, the consistent watering regimes in greenhouse experiments likely create 
Fig. 2 Mean productivity $( \pm 1$ SE) of each native (a) and non-native (b) perennial species from 1998 to 2002 . Key to symbols: solid circles, no exotic perennial competitors (NP); open circles, with exotic perennial competitors $(\mathrm{NP}+\mathrm{EP})$, closed triangles, no native competitors (EP); open triangles, with native perennial competitors $(\mathrm{NP}+\mathrm{EP})$. Asterisks indicate statistical significance between treatments within a given year: $+0.10<P>0.05$; $* P<0.05$
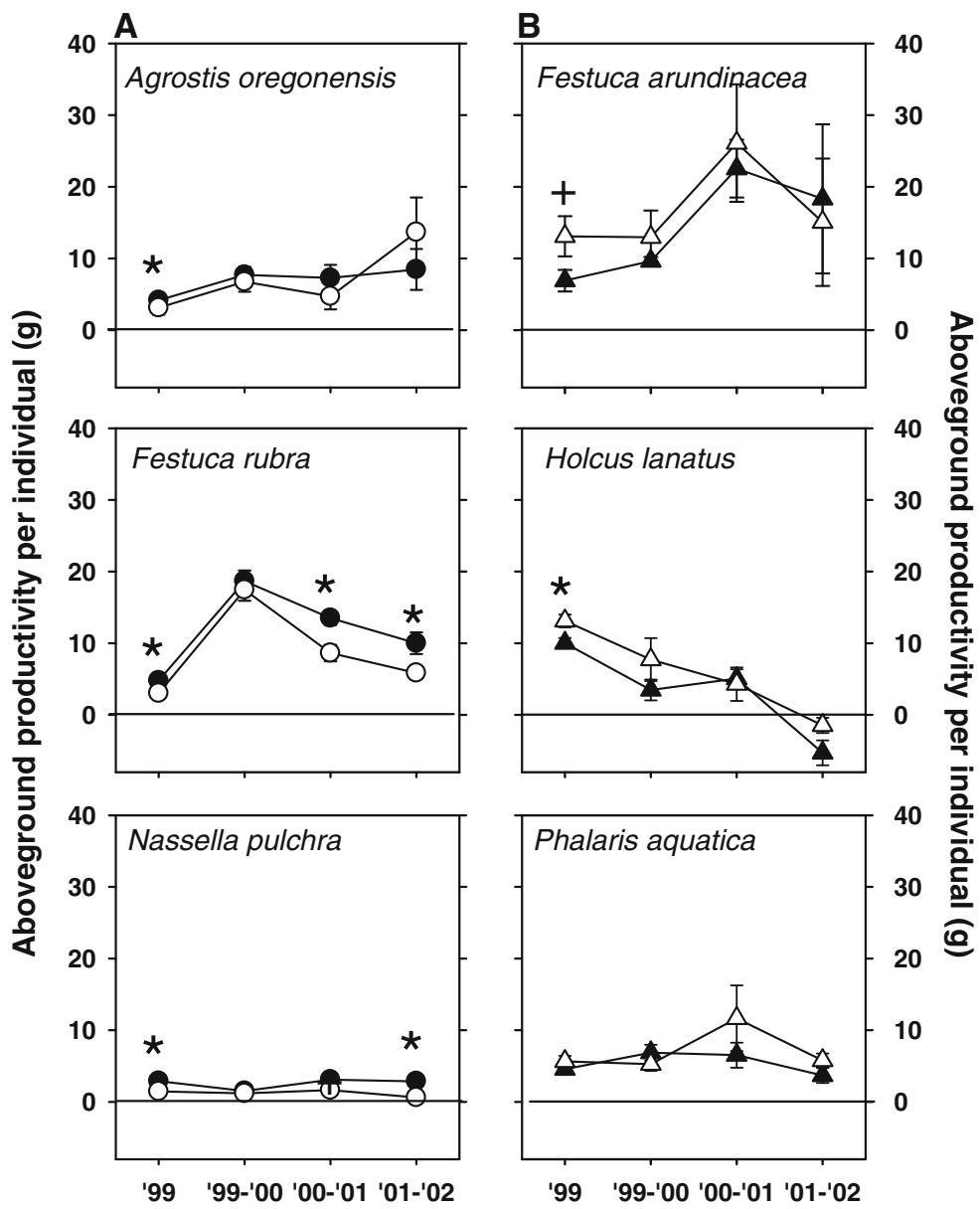

different conditions than field experiments followed over several years of widely varying rainfall.

Life history and competitive interactions

This study can also be compared to a simultaneous experiment that examined the competitive interactions between the same native species with three exotic annual species (Corbin and D'Antonio 2004b). The two experiments differed in that the exotic perennial grasses were added in a replacement design, while the exotic annual grasses were added in an additive design. Despite this, in both casescompetition with exotic annual or exotic perennial grasses - the productivity of native perennial grasses was significantly lower when intergroup competition took place (Fig. 3a, b upper panels). However, while exotic perennials experienced no reduction in productivity when competing with native perennial grasses, exotic annual grasses were significantly less productive in the presence of the native grasses (Fig. 3a, b lower panels; Corbin and D'Antonio 2004b). Thus, while the perennial-annual interactions were more symmetrical with both groups experiencing a reduction in growth, the perennial-perennial interactions were asymmetrical, favoring the nonnative group.

Our results suggest that the exotic perennial grasses in our system can be successful; yet, they do not possess any novel trait of which we are aware: the native and exotic perennial grasses were closely matched in terms of their growth form, phenology, influences on soil nitrogen dynamics, and allocation to roots versus shoots (Thomsen et al. 2006; Corbin and D'Antonio, unpublished manuscript). Though there could be such "novel weapons" as root exudates or root-associated changes in soil microbial communities (Callaway and Ridenour 2004; 


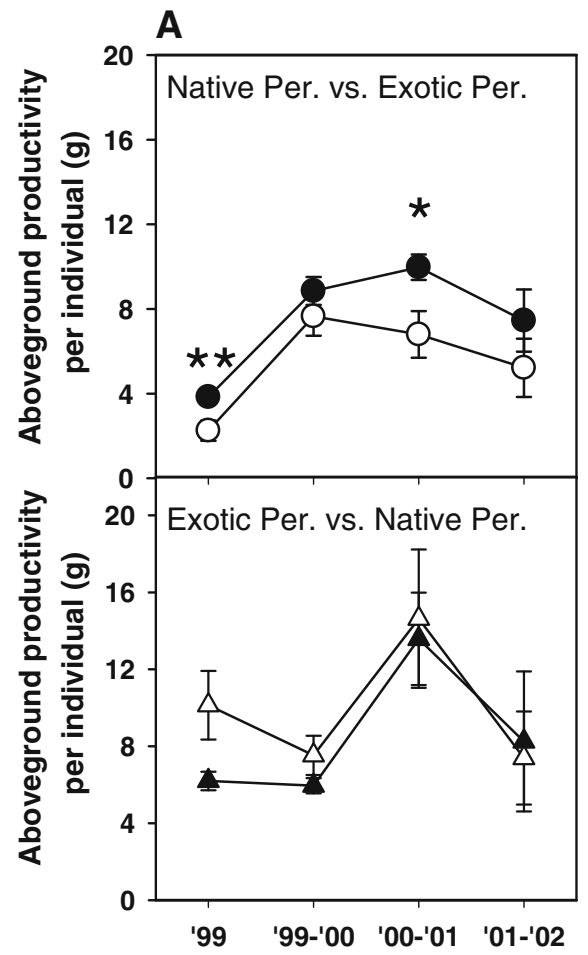

Fig. 3 (a) Mean productivity ( \pm 1 SE) of native perennial grasses with and without exotic perennial competitors (top panel) and exotic perennial grasses with and without native competitors (bottom panel); (b) mean productivity ( $\pm 1 \mathrm{SE})$ of native perennial grasses with and without exotic annual competitors (top panel) and exotic annual grasses with and without native perennial competitors. See Corbin and D'Antonio (2004b) for details. Key to symbols: solid circles,
B

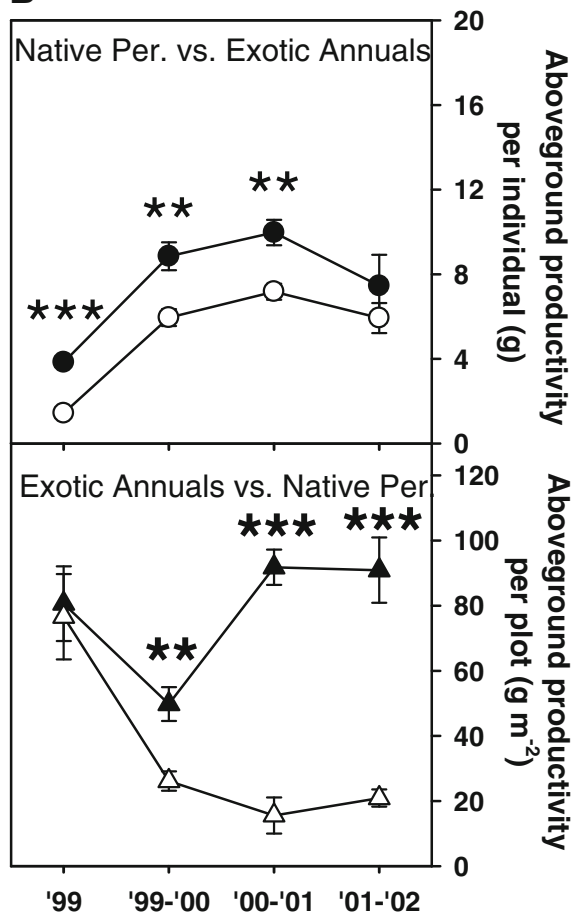

no exotic competitors (NP); open circles, with exotic competitors (NP + EP or NP + EA); open triangles, no native competitors (EP or EA); closed triangles, with native competitors (NP + EP or NP + EA). Note difference in scale between graphs. Asterisks indicate statistical significance between treatments in a given year: $* P<0.05$; ** $P<0.01 ; * * * P<0.001$

Table 3 Mean ANOVA ( \pm 1 SE) reproductive output of each species in 2000-2001

\begin{tabular}{lllccl}
\hline & $\mathrm{NP}$ & $\mathrm{EP}$ & $\mathrm{NP}+\mathrm{EP}$ & $F$ value & $P<F$ \\
\hline Agrostis & $0.68 \pm 0.21$ & - & $0.59 \pm 0.27$ & 0.2 & 0.7 \\
F. rubra & $2.09 \pm 0.61$ & - & $1.22 \pm 0.53$ & 2.2 & 0.2 \\
Nassella & $229.25 \pm 46.19$ & - & $130.75 \pm 45.54$ & $\mathbf{5 . 7}$ & $\mathbf{0 . 0 4}$ \\
F. arundinacea & - & $0.76 \pm 0.21$ & $3.33 \pm 1.50$ & $\mathbf{3 . 9}$ & $\mathbf{0 . 0 7}$ \\
Holcus & - & $1.11 \pm 0.29$ & $0.83 \pm 0.27$ & 1.0 & 0.4 \\
Phalaris & - & $0.79 \pm .29$ & $2.76 \pm 0.52$ & $\mathbf{7 . 4}$ & $\mathbf{0 . 0 2}$ \\
\hline
\end{tabular}

ANOVA analysis compared difference between treatments with a single group (NP or EP) and both groups (NP + EP). Units for all species except Nassella are seed mass (g per three individuals). For Nassella, units are seed number (seeds or spikelets per three individuals). Bold indicates effects significant $<0.10$

Note: Treatments: native perennial only (NP), exotic perennial only (EP), and native + exotic $(\mathrm{NP}+\mathrm{EP})$

Callaway et al. 2004), we found no evidence of differences in arbuscular mycorrhizal fungal communities associated with the two groups of species (Hausmann et al. unpublished manuscript). In general then, it appears that exotic perennial grasses interact with their environment in similar ways as the native perennial grasses-only more effectively turning resources into biomass. Thus it is really the 
competitive ability, and not any unique trait, which will likely lead to their population growth in native perennial-dominated grasslands.

Although relatively few studies have directly tested competitive interactions between native and non-native species that share most life-history and phenology traits, we know from several other study systems that exotics similar to natives can be superior competitors. Among the few examples is the invasion of Spartina alterniflora Lois.(smooth cordgrass) into Pacific salt marshes due to, among other factors, the ability of $S$. alterniflora to reduce growth of the native congener Spartina foliosa Trin. (California cordgrass) (Callaway and Josselyn 1992). In agricultural settings, a variety of grasses are capable of invading Triticum aestivum L. (wheat) fields, reducing yield via competition (for review see Vilà et al. 2004). Most of the other examples of invasive plants displacing native species involve the introduction of novel traits that provide an advantage for the invader either in competition or under newly altered conditions. For example, the invasion of Bromus tectorum L. (cheatgrass) into semiarid shrublands of North America has dramatically increased the frequency of fire, thereby decreasing the survival of the fireintolerant previously dominant shrubs while the annual grasses recover quickly after fire (e.g., D'Antonio and Vitousek 1992; Knapp 1996). The invasion of California south coastal grasslands by Mesembryanthemum crystallinum L. (crystalline iceplant) is aided by its salt concentrating ability that changes soil salinity. This ability is lacking in native species (Vivrette and Muller 1977). Dominance of Centaurea solstitialis L. (yellow starthistle), a summer-active annual species, into western North American grasslands is aided by its ability to access deep stores of water that are unexploited by the winter-annual dominant grassland vegetation (Sheley and Larson 1995; Gerlach 2004; Enloe et al. 2004). Callaway and Aschehoug (2000) reported that the ability of Centaurea diffusa Lam. (diffuse knapweed) to invade and successfully compete with native species in North American short-grass prairie is influenced by the production of allelopathic compounds via root exudates. In each of these cases, the success of the invader is likely partially explained by the presence of a unique trait.
Implications for control

The similarity in traits between the native and nonnative perennial grasses in California coastal prairie complicates management of these grasslands. Ideally, successful control of invasive species limits collateral damage to native species (Simberloff and Stilling 1996; Kotanen 1997), and many control or restoration strategies rely on differences between native and non-native species to avoid impacts on native populations (Hoddle 2004). Yet, strategies likely to succeed against exotic perennial grasses are also likely to negatively influence native grass populations.

Prescribed fire and grazing are among the mostoften applied management strategies in grassland ecosystems for the purposes of restoration of native biodiversity (Bakker 1989; Hayes and Holl 2003; Corbin et al. 2004; Huntsinger et al. 2007; Reiner 2007). Often, such treatments are specifically timed to take advantage of the earlier growth and flowering time of the exotic annual species compared to the native perennials-e.g., grazing in March rather than June (Love 1944; Huntsinger et al. 2007). Yet, exotic perennial grasses overlap greatly in their phenology with native perennial species. Foin and Hektner (1986) documented the replacement of annual species with exotic perennial grasses at Sea Ranch following the cessation of grazing. Such replacement of annual grasses with exotic perennial grasses has been supported by anecdotal observation in other preserves such as Bodega Marine Reserve (Sonoma County, CA) and Pt. Reyes National Seashore (Marin County, CA) (P. Connors, personal communication). Johnson and Cushman (2007) observed the pattern in reverse: the reintroduction of Cervus elaphus nannodes (Tule elk) to Pt. Reyes resulted in decreased abundance of both $H$. lanatus and native perennial grasses, while the abundance of both native and non-native annual species increased.

Relatively time-consuming strategies such as hand-pulling and targeted herbicide remain the best strategies to control exotic perennial species. Native perennial grasses and forbs have been able to maintain dominance and resist invasion by nonnative annual grasses and forbs in some relatively undisturbed habitats, particularly in coastal parts of the state (Fig. 1; Stromberg et al. 2001; Ford and Hayes 2007). However, in recent decades the 
abundance of exotic perennial grasses has increased even in relatively undisturbed grasslands. Our experimental findings along with Thomsen et al. (2006) corroborate the observation that exotic perennial grasses may be a threat to coastal native grasslands over the long term because of their greater competitive ability compared to the native species.

Acknowledgments We thank Meredith Thomsen for assistance and input through all stages of this project. J. Abraham, T. Bouchier, C. Divittorio, K. Haubensak, S. Poetker, and other members of C. D'Antonio's lab group generously assisted with fieldwork. John Kelly and Audubon Canyon Ranch provided access to Tom's Point Preserve. We also thank an anonymous reviewer for comments that improved our manuscript. The National Science Foundation (DEB 9910008) and the Marin Community Foundation provided financial support.

Open Access This article is distributed under the terms of the Creative Commons Attribution Noncommercial License which permits any noncommercial use, distribution, and reproduction in any medium, provided the original author(s) and source are credited.

\section{References}

Bakker JP (1989) Nature management by grazing and cutting. Kluwer, Dordrecht, The Netherlands

Cal-IPC (2006) California invasive plant inventory. California Invasive Plant Council, Berkeley, CA. http://www.cal-ipc. org/ip/inventory/pdf/Inventory2006.pdf

Callaway RM, Aschehoug ET (2000) Invasive plants versus their old and new neighbors. Science 290:521-523

Callaway JC, Josselyn MN (1992) The introduction and spread of smooth cordgrass (Spartina alterniflora) in south San Francisco Bay. Estuaries 15:218-226

Callaway RM, Ridenour WM (2004) Novel weapons: invasive success and the evolution of increased competitive ability. Front Ecol Environ 2:436-444

Callaway RM, Thelen GC, Rodriquez A, Holben WE (2004) Soil biota and exotic plant invasion. Nature 427: 731-733

Chiariello NR (1989) Phenology of California grasslands. In: Huenneke LF, Mooney HA (eds) Grassland structure and function: California annual grassland. Kluwer Academic Publishers, Dordrecht, The Netherlands

Corbin JD, D'Antonio CM (2004a) Can carbon addition increase the competitiveness of native grasses: a case study from California. Restor Ecol 12:36-43

Corbin JD, D'Antonio CM (2004b) Competition between native and exotic grasses in California: implications for an historical invasion. Ecology 85:1273-1283

Corbin JD, D'Antonio CM, Bainbridge S (2004) Tipping the balance in the restoration of native plants: experimental approaches to changing the exotic:native ratio in
California grassland. In: Gordon $\mathrm{M}$, Bartol S (eds) Experimental approaches to conservation biology. University of California Press, Berkeley

Corbin JD, Thomsen MA, Dawson TE, D'Antonio CM (2005) Summer water use by California coastal prairie grasses: fog, drought, and community composition. Oecologia 145:511-521

Corbin JD, Dyer A, Seabloom E (2007) Competitive relations in California grasslands. In: Stromberg MR, Corbin JD, D'Antonio CM (eds) California grasslands: ecology and management. University of California Press, Berkeley

D'Antonio CM, Vitousek PM (1992) Biological invasions by exotic grasses, the grass/fire cycle, and global change. Annu Rev Ecol Syst 23:63-87

Elton CS (1958) The ecology of invasions. Methuen, London, UK

Enloe SF, DiTomaso JM, Orloff SB, Drake DJ (2004) Soil water dynamics differ among rangeland plant communities dominated by yellow starthistle (Centaurea solstitialis) annual grasses, or perennial grasses. Weed Sci 52:929-935

Foin TC, Hektner MM (1986) Secondary succession and the fate of native species in a California coastal prairie community. Madroño 33:189-206

Ford LD, Hayes GF (2007) Northern coastal scrub and coastal prairie. In: Barbour MG, Keeler-Wolf T, Shoenherr AA (eds) Terrestrial vegetation of California, 3rd edn. University of California Press, Berkeley

Funk JL, Cleland EE, Suding KN, Zavaleta ES (2008) Restoration through reassembly: plant traits and invasion resistance. Trends Ecol Evol 23:695-703

Gerlach JD (2004) The impacts of serial land-use changes and biological invasions on soil water resources in California, USA. J Arid Environ 57:365-379

Hayes GF, Holl KD (2003) Cattle grazing impacts on annual forbs and vegetation composition of mesic grasslands in California. Conserv Biol 17:1694-1702

Heady HF (1958) Vegetational changes in the California annual type. Ecology 39:402-416

Heady HF (1988) Valley grassland. In: Barbour MG, Major J (eds) Terrestrial vegetation of California, 2nd edn. California Native Plant Society, Sacramento

Hoddle MS (2004) Restoring balance: using exotic species to control invasive exotic species. Conserv Biol 18:38-49

Huntsinger L, Bartolome JW, D'Antonio CM (2007) Grazing management in California's Mediterranean grasslands. In: Stromberg MR, Corbin JD, D'Antonio CM (eds) California grasslands: ecology and management. University of California Press, Berkeley

Johnson BE, Cushman JH (2007) Influence of large mammal reintroduction on plant invasions and community composition in a California grassland. Conserv Biol 21:515526

Knapp PA (1996) Cheatgrass (Bromus tectorum L.) dominance in the Great Basin Desert: history, persistence an influences of human activity. Glob Environ Change 6:37-52

Kotanen PM (1997) Effects of experimental soil disturbance on revegetation of natives and exotics in coastal California meadows. J Appl Ecol 34:631-644

Love RM (1944) Preliminary trials on the effect of management on the establishment of perennial grasses and 
legumes at Davis, California. J Am Soc Agron 36:699703

Maron JL, Jefferies RL (2001) Restoring enriched grasslands: effects of mowing on species richness, productivity and nitrogen retention. Ecol Appl 11:1088-1100

Marty JT (2005) Effects of cattle grazing on diversity in ephemeral wetlands. Conserv Biol 19:1626-1632

Peart DR (1989) Species interactions in a successional grassland. III. Effects of canopy gaps, gopher mounds and grazing on colonization. J Ecol 77:267-289

Reiner RJ (2007) Fire in California grasslands. In: Stromberg MR, Corbin JD, D'Antonio CM (eds) California grasslands: ecology and management. University of California Press, Berkeley

SAS Institute (2002) SAS for Windows v. 9.1.3. Cary, NC

Scheiner SM (1993) MANOVA: multivariate response variables and multispecies interactions. In: Scheiner SM, Gurevitch $\mathbf{J}$ (eds) Design and analysis of ecological experiments. Chapman and Hall, New York

Sheley RL, Larson LL (1995) Interference between cheatgrass and yellow starthistle at 3 soil depths. J Range Manag 48:392-397

Simberloff D, Stilling P (1996) Risk of species introduced for biological control. Biol Conserv 78:185-192

Stock WD, Wienand KT, Baker AC (1995) Impacts of invading $\mathrm{N}_{2}$ fixing Acacia species on patterns of nutrient cycling in two Cape ecosystems: evidence from soil incubation studies and ${ }^{15} \mathrm{~N}$ natural abundance values. Oecologia 101:375-382

Stohlgren TJ, Crosier C, Chong GW, Guenther D, Evangelista P (2005) Life-history habitat matching in invading nonnative species. Plant Soil 277:7-18

Stromberg MR, Kephart P (1996) Restoring native grasses in California old fields. Restor Manag Notes 14:102-111

Stromberg MR, Kephart P, Yadon V (2001) Composition, invasibility, and diversity in coastal grasslands. Madroño 48:236-252

Thomsen MA, Corbin JD, D'Antonio CM (2006) The effects of soil nitrogen on competition between native and exotic grasses from coastal northern California. Plant Ecol 186:25-35

Vilà M, Williamson M, Lonsdale M (2004) Competition experiments on aliens weeds with crops: lessons for measuring plant invasion impact? Biol Invasions 6:59-69

Vitousek PM, Walker L, Whiteaker L, Mueller-Dombois D, Matson P (1987) Biological invasion by Myrica faya alters ecosystems development in Hawaii. Science 238:802-804

Vivrette N, Muller CH (1977) Mechanism of invasion and dominance of coastal grassland by Mesembryanthemum crystallinum. Ecol Monogr 47:301-318 